\title{
ON A PECULIAR DISPLACEMENT IN THE MILLEPORE OOLITE NEAR SOUTH CAVE.
}

By J. W. Stather, F.G.S.

A section in the Millepore Oolite on the Hull and Barnsley Railway, close to South Cave Station, and on the south side of the line, was described in 1883 by Keeping and Middlemiss* as follows :-

"The cutting now entered is twelve feet in the highest part and 792 feet long. The rock is uniform in character-being a characteristic well-bedded Oolite, quite like the Millepore Oolite of the Howardian Hills. Oolite grains form the mass of the rock."

The beds of this cutting have been recently excavated on an extensive scale by The Grey Stone Company, Ltd., and the quarrying back of the limestone has revealed some unexpected features.

The most important of these is the occurrence of an irregular band of flinty and chalky rubble-drift, beneath a mass of displaced Millepore limestone, partly shattered, but in some places maintaining its original bedding, so that except for the evidence of the section it might have been regarded as in situ.

The Millepore Oolite and Estuarixe Sands.

In working back into the hill, the section rapidly increased in height, and the sands of the Estuarine Oolite and Kellaways Rock, $\uparrow$ normally overlying the Millepore in this district, set in at the top, and in some parts of the section rapidly attained as much as 14 feet in thickness. The sands appeared to be disturbed, and were unevenly distributed, in some places occupying hollows in the underlying Millepore, apparently due to displacement of some kind. The Millepore Limestone itself shewed unmistakable signs of disturbances, for, though the main lines of bedding are well maintained, they are almost throughout the section bent and shattered, shewing open joints, cracks and large cavities. It seems likely that this condition is due to irregular slipping of the Millepore beds down the hillside into Drewton Valley, and this explanation becomes all the more probable when we remember that the Millepore Limestone is here underlain by wet and slippery

* Geol. Mag., dec. II., Vol. X., p. 216.

† Fox-Strangways, Jurassic Rocks of Britain-Yorkshire, Vol. I., pp. 260 and 290. 


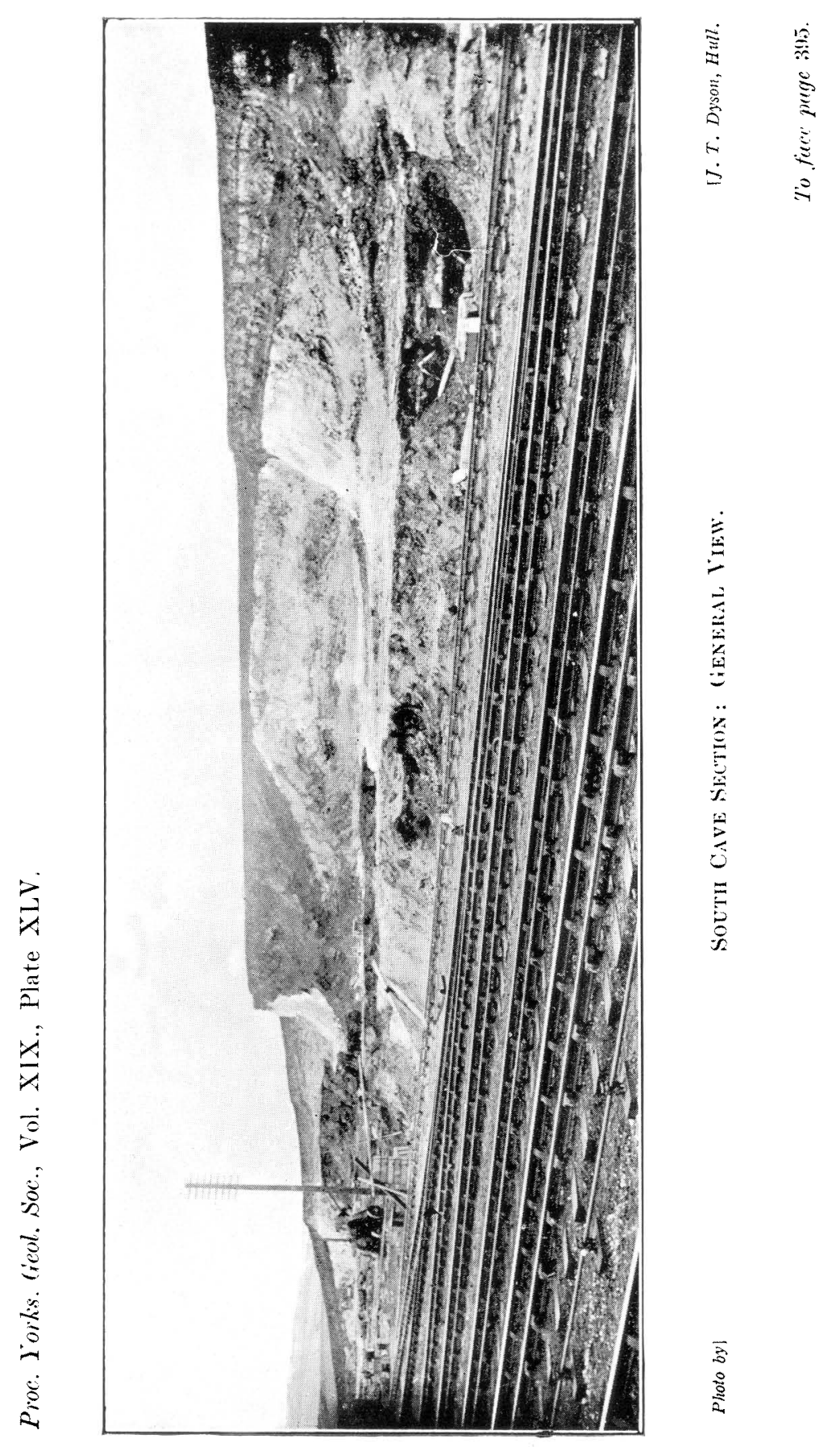




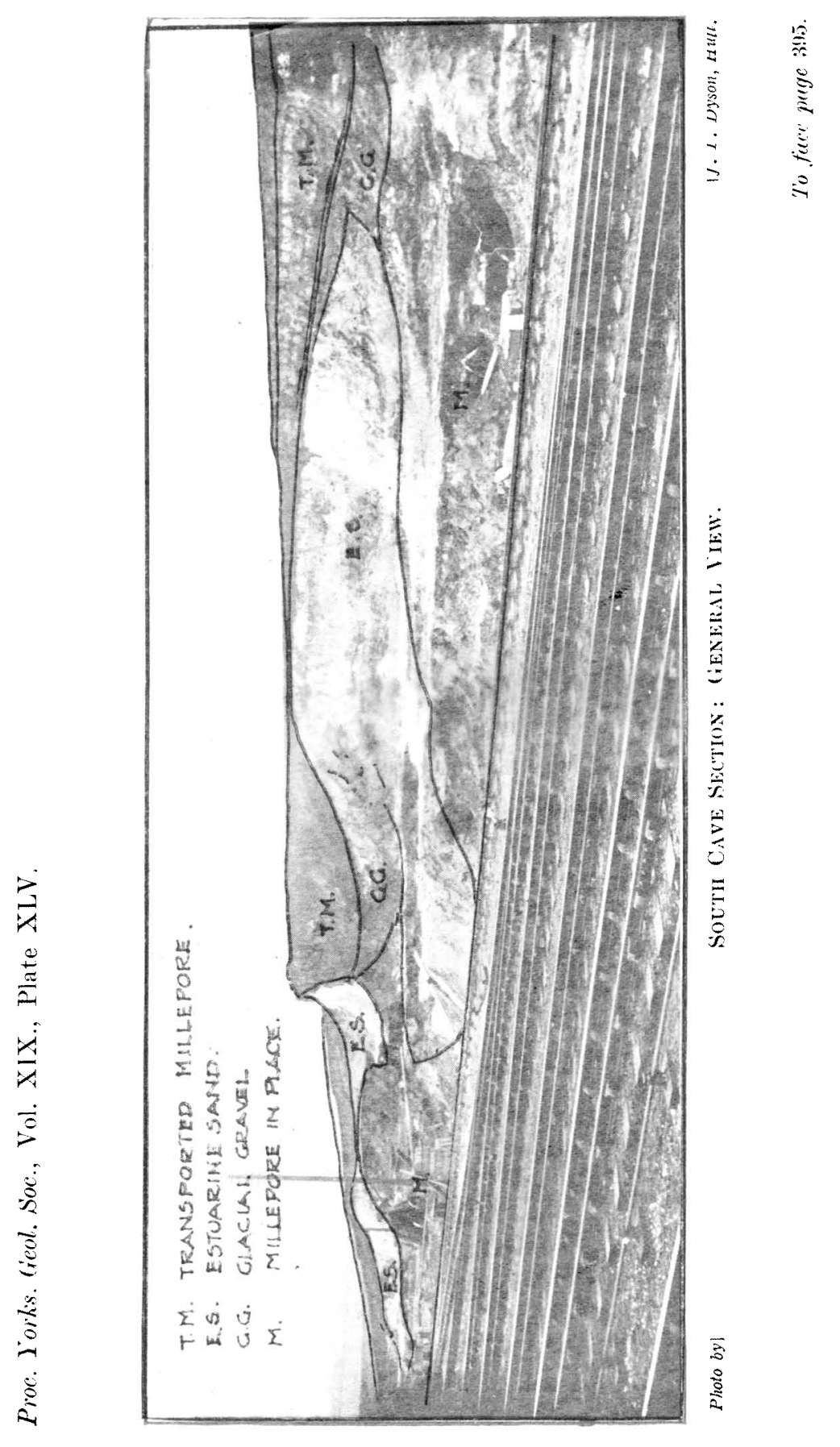


Lias shales, and that the thin Lower Estuarine Clays and sands which usually underlie the Millepore* appear to be absent at this point. The Lias shales were well seen in a large trial hole, twelve feet below the floor of the quarry, and the following fossils were collected from them :-Protocardia truncata (J. de C. Sow.), Pholodomya cf. ambigua J. Sow., Pleuromya costata? Y. and B., Ceromya?

The displacements in the lower part of the section appear to be quite independent of the curious complications in the higher part associated with the rubble drift, and are probably of earlier date.

\section{The Rubble-Drift.}

The lowest drift-deposit is an irregular band, ranging up to $6 \mathrm{ft}$. in thickness, and consists of fragments of flint and chalk up to several inches in diameter, along with occasional pieces of Red Chalk and some larger fragments of Millepore Limestone, set in a matrix of gritty chalk-wash like that seen underneath the drifts in some of the deeper hollows of the Chalk on Flamborough Head. The band first made its appearance when the quarry had been cut back a few feet from the original face, and it is not continuous at present through the whole of the section.

A few stones foreign to the district have been found in this material. Prof. P. F. Kendall, M.Sc., has kindly examined five of these, and remarks as follows :-

No. 1.-Quartz porphyry, origin unknown.

No. 2.-Crushed and sheared granite, origin unknown; not English, but may be British.

No. 3.-A fine grained felsite with tourmaline.

No. 4.-Decomposed porphyrite of the Cheviot type.

No. 5.-Red Sandstone; might have come from Millstone Grit or Old Red.

\section{The Clay Band.}

Usually at the top of this chalky rubble-drift there are a few inches of dark blue or blackish clayey material of problematic origin. On washing this clay, it is found to contain fragments of a small Pentacrinus, which suggests that the material has been derived from

* Ibid., p. 204. 
the Lias occurring below the Millepore rock. Some minute tubular cavities in the clay are suggestive of rootlets of vegetation such as might indicate an old land surface, but no carbonaceous matter has been found, or any other proof of land conditions. The clay band is in some places crumpled and contorted.

This clay-seam beneath the displaced sheet of limestone has apparently formed the gliding plane on which the limestone has slid.

\section{The Displaced Millepore Limestone.}

Immediately above the clay band, there was in October, 1920, a displaced sheet of Millepore Oolite-sometimes shattered, sometimes in long tabular bedded masses-extending to the top of the section as seen at present. In thickness this displaced Oolite varied from 3 feet to 12 feet, and was seen for a length of 300 feet.

The presence of the Millepore limestone in this situation, not only above the chalky rubble, but also above the Estuarine Sand, can only be explained by supposing the limestone has been carried over the newer deposits by some transporting agency, presumably Glacial. There is no place in the immediate neighbourhood from which the Millepore Oolite could have slipped by gravity into its present position.

During the past two years the face of the quarry has been carried back at least ten yards, and the sections exposed have been constantly under observation. As might be expected, the Millepore beds at the base and the Sands above them, owing to their disturbed and shaken condition, have shown constant change in detail as the section was cut back, but they have maintained their relative positions. The rubble-drift also has shown much variation in thickness and arrangement. On the other hand, the narrow band of clay above the drift has shewn little alteration, and has persisted uniformly underneath the displaced slabs of Millepore. The displaced limestone itself has gained in thickness and regularity as the excavation has been carried deeper into the hill.

It would be premature to attempt at present a complete explanation of this puzzling section, as the full extent of the displacement has not yet been disclosed. It is, however, now evident that the complications include two distinct factors :-

(1) The confusion due to the irregular downward movement of the Millepore beds, caused by slips or creep over the shaly Lias, brought 


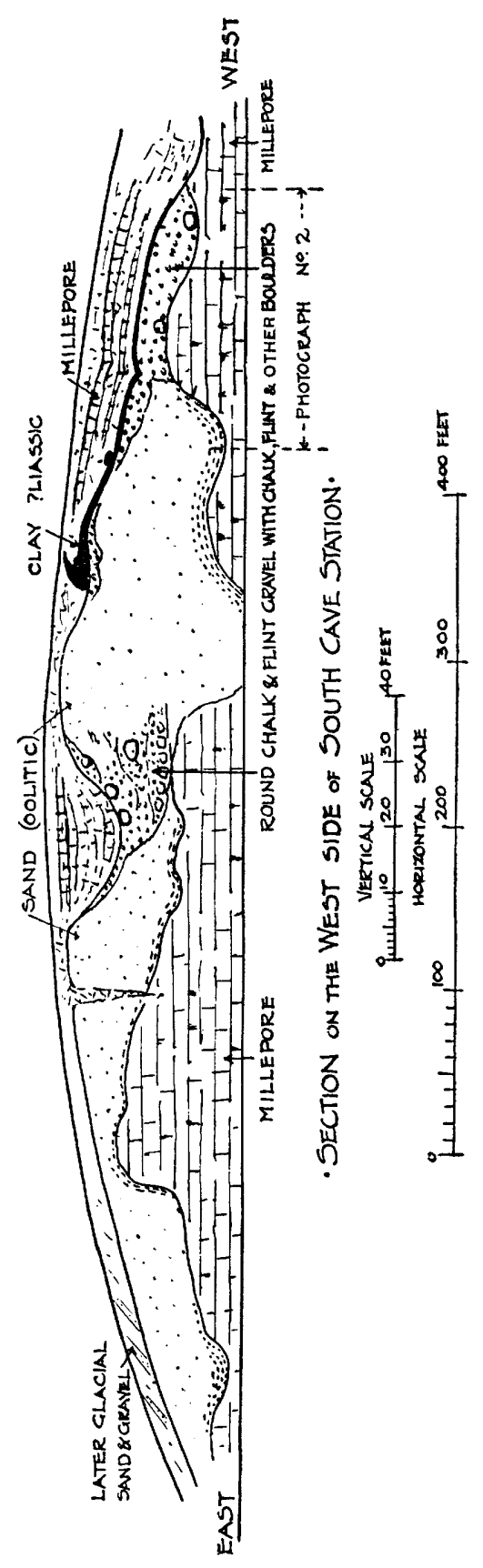




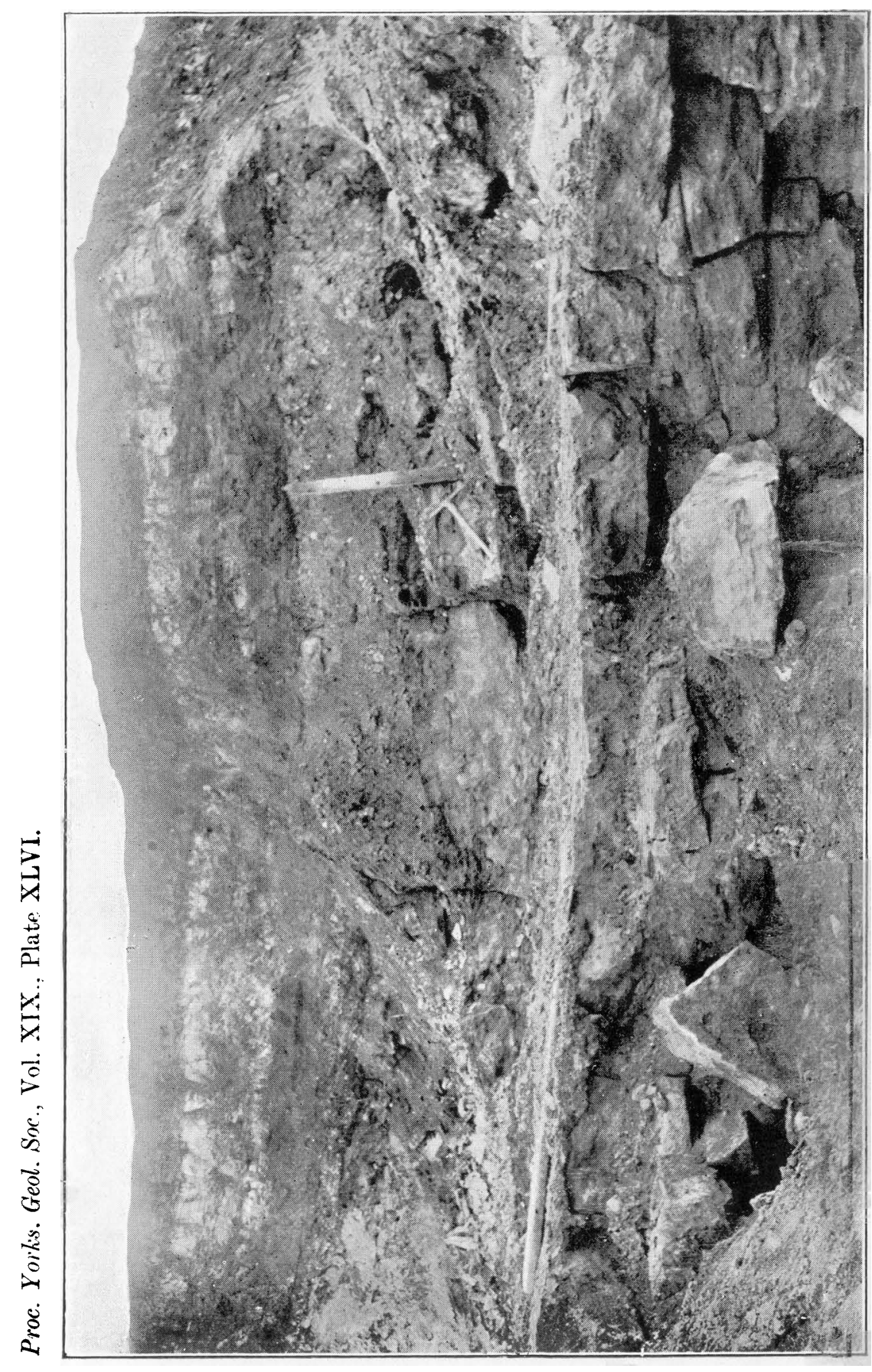

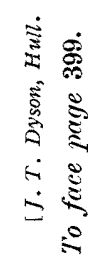

छ

畜

-

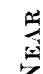

.

范

总

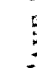

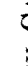

章

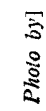




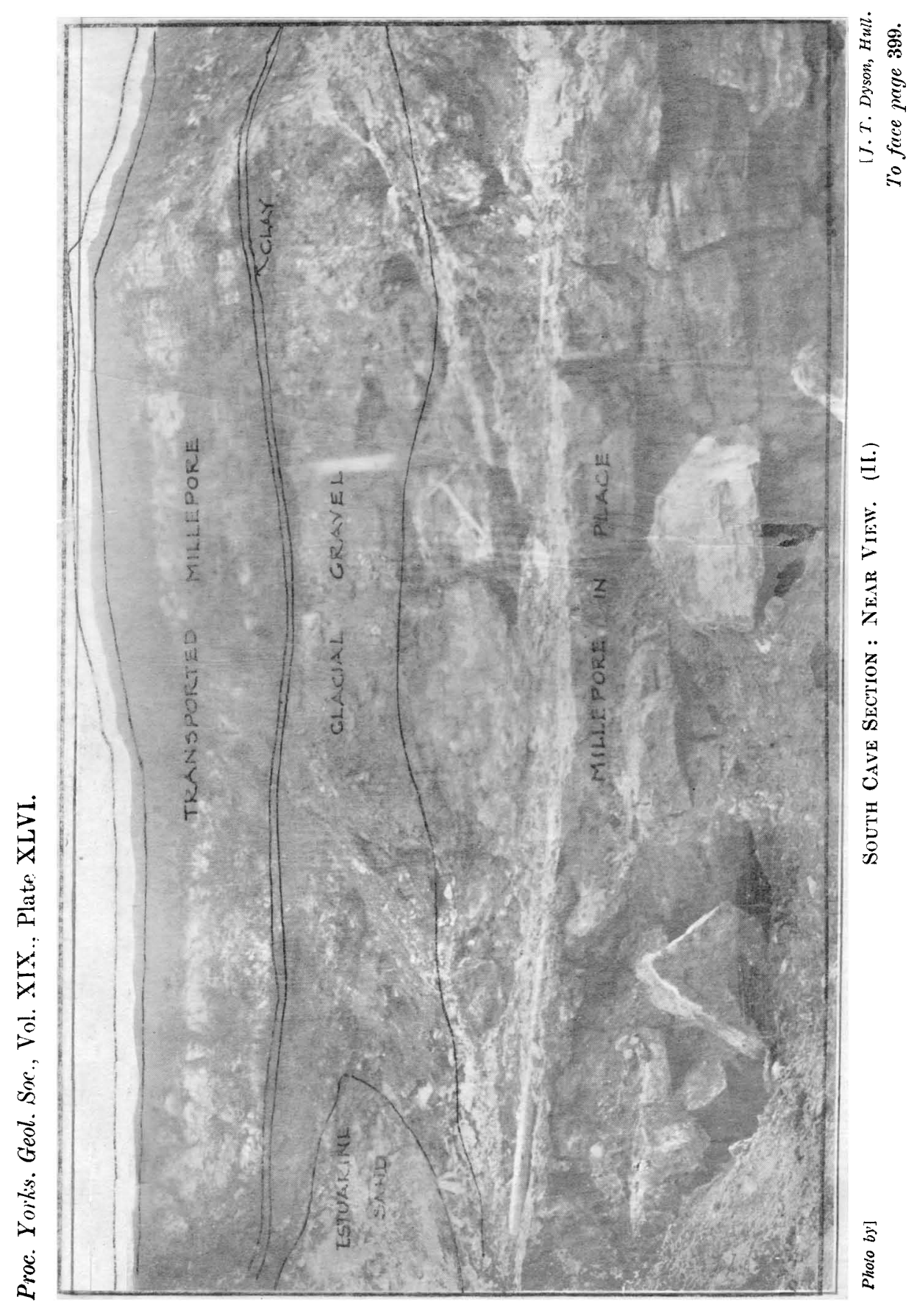


about by the action of springs and the erosion of the valley of the Drewton Beck. There is likewise the possibility of the rocks being affected still earlier by a small strike fault.

(2) A later displacement of the sheet of Millepore Oolite above the Glacial rubble at the top of the section, which must apparently be attributed to some kind of Glacial action.

As to the mode of this Glacial action, no conclusion can at present be reached. The absence of boulder clay and the predominance of local detritus in the gravelly drift tell against the supposition that the transport is the result of the direct impact of the great Eastern Icesheet. It has, however, long been postulated that when the estuary of the Humber was blocked by this ice-sheet-of which the boulder clay at North Ferriby is believed to mark the moraine-the low ground west of the Yorkshire Wolds must have been occupied by a lake, to which the name "Lake Humber" has been applied.* There are several features in the South Cave section which suggest that the shore of this old lake may at one time have been situated in this quarter. If so, the displacement of the limestone may have been due to the winter freezing of the shallow waters and the shifting of portions of the rock-floor when the ice broke up, and was driven inshore in the summer.

It is to be noted that the curious mass of rubble-drift at Sancton, $\dagger$ which has some features in common with the South Cave drifts-notably the presence of a clay-streak-occurs nearly at the same level-about 170 feet above sea-level. Also that the mammaliferous Glacial gravel at Mill Hill, Elloughton, described by Lamplugh and Sheppard, occurs at about 115 feet above sea-level.

Since the above paper was read to the Society, Prof. Kendall has kindly sent me the following valuable notes relating to the lacustrine deposits of the Vale of York :-

"The alluvial plain of the Lower Ouse, Aire and Trent, extending from the Escrick moraine down to the latitude of Bantry, and from the Magnesian Limestone outcrop in the West to the Jurassic escarpment of the East Riding of Yorkshire and North Lincolnshire, is mainly constituted of warp clays, long recognised as of lacustrine origin. They attain a thickness of 200 feet at Barnby Dun.

* Carvill Lewis, Extra Morainic Lakes, Geol. Mag., dec. III., Vol. IV., pp. 515 to 517. Kendall, Glacier Lakes in the Cleveland Hills, Quart. Journ. Geol. Soc., Vol. LVIII. p. 567. $\dagger$ Trans. Hull. Geol. Soc., 1894, Vol. II., p. 10. 
"A very significant section is exposed at Harworth, about 8 miles S.E. of Doncaster. About 20 feet of clay is exposed in a brickyard. When seen in 1896, the clay appeared to be devoid of lamination or bedding, but sections now visible show both features well. On some faces the stratification is thrown in great rolls and minor contortions, often enclosing masses of stratified sand. These eyes of sand vary in size from an inch in diameter up to several feet. The stratification may be at any angle to the horizontal, and in the larger bodies is, besides, being abruptly cut off at the ends. The smaller inclusions may be crowded together like the pebbles in a gravel, and all, whether large or small, have, it is suggested, been moved in a frozen condition.

"The interpretation offered is that the deposit was laid down in a lake subject to severe freezing and drifting of floating ice, which contorted the deposits when it grounded.

"There are many pebbles and boulders, chiefly of local rocks, but a peculiar significance attaches to the frequent occurrence of glaciated blocks of hard Chalk of the type found in the Wolds of Yorkshire and Lincolnshire, accompanied by large tabular grey flints of the same provenance. One specimen was found of fossiliferous oolitic limestone of a very distinctive type, recognised by Mr. M. Odling as exactly resembling a rock he has observed on the Hambledon Hills. The altitude at which this deposit occurs is about 100 feet above sea-level."

In conclusion, I should like to thank Prof. P. F. Kendall, M.Sc., and Mr. G. W. Lamplugh, F.R.S., for many helpful suggestions during the preparation of these notes; and also to mention how much $I$ am indebted to Mr. W. H. Crofts for obtaining detailed measurements of the section from time to time, and supplying the illustration on page 398 and the map. Thanks are also due to Mr. J. T. Dyson for the photographs, and also to Mr. Thos. Sheppard, M.Sc., for help in the field and in many other ways. 


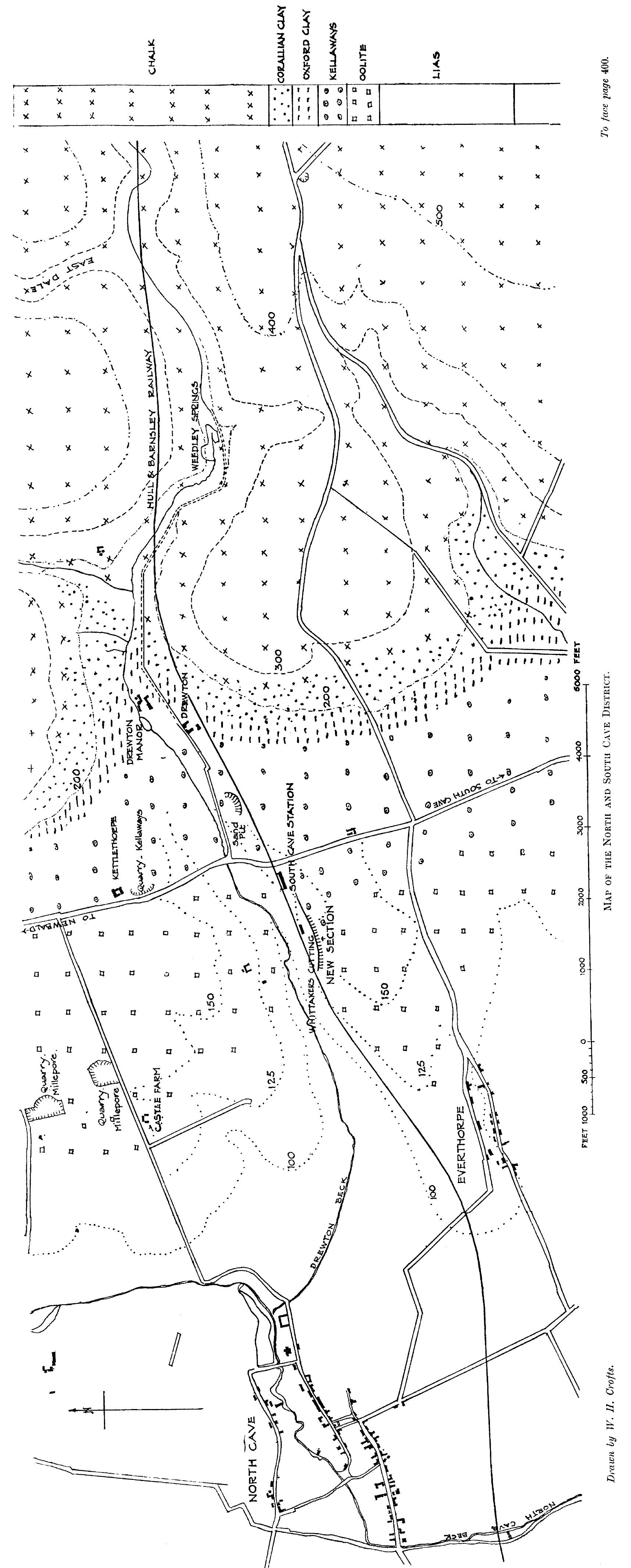

